\title{
REVIEW
}

\section{Phosphatidylserine, a death knell}

\author{
RA Schlegel ${ }^{*, 1}$ and P Williamson ${ }^{2}$ \\ 1 Department of Biochemistry and Molecular Biology, Penn State University, \\ University Park, PA 16802, USA \\ 2 Department of Biology, Amherst College, Amherst, MA 01002, USA \\ * Corresponding author: RA Schlegel, Department of Biochemistry and \\ Molecular Biology, 428 South Frear Laboratory, Penn State University, \\ University Park, PA 16802, USA. Tel: (814) 865-6974; Fax: (814) 863-7024; \\ E-mail: ur3@psu.edu
}

Received 30.8.00; revised 13.11.00; accepted 27.11.00 Edited by M Piacentini

\begin{abstract}
Virtually every cell in the body restricts phosphatidylserine (PS) to the inner leaflet of the plasma membrane by energydependent transport from the outer to the inner leaflet of the bilayer. Apoptotic cells of all types rapidly randomize the asymmetric distribution, bringing PS to the surface where it serves as a signal for phagocytosis. A myriad of phagocyte receptors have been implicated in the recognition of apoptotic cells, among them a PS receptor, yet few ligands other than PS have been identified on the apoptotic cell surface. Since apoptosis and the associated exposure of PS on the cell surface is probably over 600 million years old, it is not surprising that evolution has appropriated aspects of this process for specialized purposes such as blood coagulation, membrane fusion and erythrocyte differentiation. Failure to efficiently remove apoptotic cells may contribute to inflammatory responses and autoimmune diseases resulting from chronic, inappropriate exposure of PS. Cell Death and Differentiation (2001) 8, 551-563.
\end{abstract}

Keywords: apoptosis; phosphatidylserine; membrane asymmetry; phagocytosis; macrophages; aminophospholipid translocase

Abbreviations: PS, phosphatidylserine; GlcNAc, N-acetylglucosamine; aPLA, anti-phospholipid antibodies

\section{Introduction}

The lipid bilayer of the plasma membrane is often considered as simply an inert sea (or a pair of parallel lines) serving as a matrix for suspending membrane proteins. This view is not dramatically dislocated by the fact that individual phospholipid

\#American Heritage Dictionary: 'a signal of disaster or destruction'; Webster's New World Dictionary: 'an omen of death'. molecules are sometimes withdrawn from the matrix and hydrolyzed to produce signaling molecules, including prostaglandins, diacylglycerol and ceramides. In recent years, however, a growing body of evidence has suggested that physical and chemical properties of the bilayer itself, such as the thickness of the hydrophobic core $^{1}$ or local lateral domains of specialized lipid composition ${ }^{2-4}$ may play significant roles in the assembly and organization of cellular membranes. In addition to these structural contributions to membrane function, the past few years have also seen the revelation that a phospholipid itself, and not a derived product, acts on the extracytosolic, external face of the plasma membrane to regulate intercellular interactions.

Appreciation of this new role for phospholipids was galvanized by the demonstration that phosphatidylserine (PS) appears on the surface of apoptotic lymphocytes and contributes to their phagocytosis by activated macrophages. $^{5}$ The functional importance of the phagocytosis of apoptotic cells would be difficult to overstate. Although in vitro assays of apoptosis often concentrate on autodigestion events such as degradation of nuclear DNA or of specific proteins, apoptosis in vivo is primarily a process of cell removal. Indeed, the bulk of autodigestion occurs after apoptotic cells have been safely segregated and are already being digested within a phagolysosome. ${ }^{6,7}$ Autodigestion alone, without phagocytosis, can leave corpses lying about. ${ }^{8}$ In organisms such as mammals, where morphological, neural and immunological development depends heavily on the elimination of unwanted cells, and where tissue inflammation is a risk of uncontrolled cell lysis, the mechanisms of apoptotic cell recognition and removal are of critical physiological importance. Moreover, the apoptotic machinery is phylogenetically very old, and may be the raison d'etre for the presence and disposition of PS in the plasma membrane bilayer.

\section{PS signals clearance by the reticuloendothelial system}

The discovery of the importance of PS for removal of apoptotic cells provided a plausible functional foundation for an older literature implicating PS as a potent signal in cell-cell interactions. The power of PS to act as a signaling molecule was clearly demonstrated over a decade ago in studies with artificial lipid vesicles, or liposomes, which had been formulated to persist in the mammalian circulation. ${ }^{9}$ When such vesicles were doped with as little as 3 mole \% PS, they were rapidly removed from the circulation by the liver and spleen. The effect was specific to PS-other anionic phospholipids would not substitute-indicating that PS alone and by itself was a signal for clearance by the reticuloendothelial system. These in vivo studies complemented prior and subsequent in vitro demonstrations that all types of 
macrophages preferentially phagocytose liposomes containing PS. ${ }^{10-15}$

The obvious question provoked by these studies is why blood cells are not similarly cleared from the circulation, given that their plasma membranes contain PS. For quite some time, it has been generally agreed that normal platelets, erythrocytes, and probably lymphocytes, neutrophils, and monocytes as well, are not cleared because PS is not exposed their cell surface, but rather is restricted to the inner leaflet of the plasma membrane bilayer. ${ }^{16-18}$ This transbilayer asymmetry in lipid composition between the inner and outer leaflet is crucial. If erythrocytes present PS on their surface, they are cleared from the circulation ${ }^{19,20}$ just as are PS-containing liposomes. Again, this behavior in vivo is seconded by studies in vitro which show that macrophages preferentially phagocytose erythrocytes with PS on their surface. ${ }^{21,22}$ The critical role of the exposed PS in provoking phagocytosis is demonstrated by the ability of PS vesicles to specifically and completely inhibit preferential uptake of erythrocytes with PS on their surface. ${ }^{23,24}$ Indirect evidence suggests that this mechanism contributes to the removal of senescent erythrocytes from the circulation. ${ }^{25}$

These studies with erythrocytes were complemented by evidence that lymphocytes which present PS on their surface interact with macrophages, whereas normal lymphocytes with PS restricted to the inner leaflet, such as those drawn from the circulation, do not interact. ${ }^{26,27}$ The realization some years later that the interacting lymphocytes were apoptotic ${ }^{5,28}$ extended to lymphocytes the concept that exposure of PS has evolved as a mechanism for eliminating effete blood cells. ${ }^{29}$ Over this same period, increased understanding of the dynamics of PS movements across the bilayer provided insight into the molecular mechanisms which underlie and regulate exposure of PS on the apoptotic cell surface.

\section{Mechanisms for maintenance and loss of PS asymmetry}

Like many other basic principles of membrane structure and function, insights into the mechanisms by which PS becomes exposed on the cell surface come from studies of erythrocytes. PS is not the only phospholipid which is asymmetrically distributed across the bilayer, although it is the only major phospholipid which is completely sequestered away from the outer monolayer. It has been known for 30 years that in the plasma membrane of the erythrocyte the choline phospholipids, phosphatidylcholine (PC) and sphingomyelin, are found predominantly in the outer leaflet of the bilayer, whereas phosphatidylethanolamine, which along with PS are the aminophospholipids, is found predominantly in the inner leaflet. ${ }^{30}$ However, it wasn't until the 1980s that the mechanism for establishing and maintaining this asymmetry began to emerge. In 1984, Seigneret and Devaux demonstrated that a spin-labeled analog of PS introduced into the outer leaflet of the plasma membrane of erythrocytes was rapidly and quantitatively transported to the inner leaflet in an ATP-dependent manner; an analog of phosphatidylethanolamine was transported with lower efficiency, and an analog of
PC not at all. ${ }^{31}$ This transport activity was termed the aminophospholipid translocase, and was also demonstrated in the membrane of chromaffin granules isolated from adrenal cells $^{32}$ and in synaptic vesicles from the electric eel. ${ }^{33}$

The synaptic vesicle, chromaffin granule, and erythrocyte membranes all contain a PS-stimulated ATPase whose activity in vitro, like the translocase activity in situ, is sensitive to vanadate and $\mathrm{N}$-ethylmaleamide. ${ }^{34-36}$ Cloning of the ATPase from chromaffin granules revealed it to be a P-type ATPase ${ }^{37}$ which identifies a new subfamily of P-type ATPases distinct from the light $\left(\mathrm{Na}^{+}, \mathrm{K}^{+}, \mathrm{Ca}^{2+}\right)$ and heavy $\left(\mathrm{Cu}^{2+}, \mathrm{Cd}^{2+}\right)$ metal ion transporter subfamilies with multiple members in yeast, slime mold, nematodes, flies, mammals, protozoa and plants. ${ }^{38,39}$ Although the substrates of other subfamily members are not known, mutations in one cause hereditary cholestasis in humans. ${ }^{40}$

The ancient pedigree of the translocase argues that lipid asymmetry is an old and general feature of eukaryotic cells. While often widely assumed to be the case, until recently arguments for this view rested heavily on the demonstration of aminophospholipid translocase activity in a range of mammalian cell types. ${ }^{17}$ However, this conclusion has now been more directly and more generally substantiated using the PS-specific probe annexin V. Van den Eijnde and coworkers $^{41}$ injected biotinylated annexin intracardially into viable mouse embryos which were subsequently fixed, sectioned and stained with horse radish peroxidase-avidin to identify those cells in which PS was exposed in vivo. Non-apoptotic cells of all types were generally unlabeled, indicating that their PS was not exposed on the outer leaflet of the plasma membrane and thus neatly demonstrating the ubiquity of PS asymmetry. Similar experiments in chick and Drosophila embryos confirm that most normal cells in these animals also sequester $\mathrm{PS},{ }^{42}$ arguing that plasma membrane lipid asymmetry was a property of the cells of the common ancestor of vertebrates and invertebrates, which lived sometime in the Precambrian, over 600 million years ago. Notably, two instances of annexin binding by non-apoptotic cells were observed: myoblasts fusing to form myotubes and myocardioblasts to form cardiac muscle, and megokaryoblasts and megakaryocytes from which thrombocytes were forming. These intriguing findings are discussed in more detail below.

While the translocase acts to establish and maintain lipid asymmetry, a separate membrane protein acts to disrupt this asymmetry. When cytosolic levels of $\mathrm{Ca}^{2+}$ are elevated in erythrocytes or platelets, PS appears on the cell surface within minutes. ${ }^{43,44}$ Although $\mathrm{Ca}^{2+}$ inactivates the translocase ${ }^{45}$ this event alone is insufficient to bring PS rapidly to the cell surface because of the slow rate of passive diffusion of phospholipids across the bilayer. ${ }^{46}$ However, $\mathrm{Ca}^{2+}$ also activates a non-specific, bi-directional lipid flipsite, distinct from the translocase and termed the scramblase. ${ }^{44,47}$ This activity rapidly randomizes the transbilayer distribution of all the plasma membrane phospholipids to produce a lipid-symmetric membrane, bringing $P S$ to the cell surface. Scramblase activity from erythrocytes $^{48}$ and platelets ${ }^{49}$ has been reconstituted with low efficiency into artificial lipid vesicles and a $37 \mathrm{kD}$ protein with one membrane-spanning domain has been 
cloned. ${ }^{50}$ However, this protein is normal in Scott syndrome patients whose blood cells are defective in scramblase activity, ${ }^{51,52}$ suggesting that other molecules are required for scramblase activity and/or activation. A similar activity has also been demonstrated in $\mathrm{T}$ cell hybridomas ${ }^{53}$ and primary thymocytes, ${ }^{54}$ where a distinct lag is seen between elevation of cytosolic $\mathrm{Ca}^{2+}$ and scramblase activity ( $P$ Williamson et al., submitted), suggesting that the activation mechanism may be complex.

\section{PS exposure in apoptosis}

Several lines of evidence indicate that exposure of PS on the cell surface is a general feature of apoptosis. The first evidence was provided by biochemical detection of PS on the surface of apoptotic but not non-apoptotic lymphocytes ${ }^{5}$ likely from a loss of overall membrane asymmetry. ${ }^{55}$ The advent of annexin binding as a simple assay for PS revealed the exposure of PS on apoptotic cells as disparate as a panel of primary and cultured hematopoietic cells, ${ }^{56}$ smooth muscle cells, ${ }^{57}$ vascular endothelial cells, ${ }^{58}$ spermatogenic cells, ${ }^{59}$ neurons ${ }^{60}$ and even cells at developing cranial sutures. ${ }^{61}$ This piecework approach has been complemented by the more global observations of van den Eijnde, ${ }^{62-67}$ where annexin binding was studied after in vivo injection. Those studies showed that cells derived from all three germ layers were labeled by annexin at sites where apoptosis occurs during embryonic morphogenesis, including neurons, bronchi, somites and degenerating tailgut and interdigital tissue. Similar conclusions were drawn from observations of mammalian, avian and insect embryos, placing the evolutionary origin of PS exposure during apoptosis, like the origin of PS asymmetry itself, to a time over 600 million years ago. Moreover, these results offer the hope that the mechanisms of recognition and elimination of apoptotic cells, like the mechanisms of apoptotic autodigestion, will show a common basis in a wide variety of different organisms.

At least for lymphocytes, coordinate regulation of the translocase and the scramblase controls the exposure of PS on the apoptotic cell surface. ${ }^{53,68}$ Activation of the scramblase rapidly brings $P S$ to the outer leaflet, driven by the standing concentration gradient across the bilayer created by the translocase, and PS remains on the cell surface so long as the translocase is inactivated. As expected, exposure of PS on apoptotic lymphocytes, detected by annexin binding, is observed at the time when activation of the scramblase and inactivation of the translocase occur, as detected by transbilayer movements of phospholipid analogs, ${ }^{69}$ with the extent of translocase inactivation suggested to determine the degree of PS exposure. $^{68}$

The mechanisms which regulate the activities of the translocase and scramblase are not known. Since artificially elevating cytosolic $\mathrm{Ca}^{2+}$ concentrations both inactivates the translocase and activates the scramblase, $\mathrm{Ca}^{2+}$ could serve as the physiologic signal regulating PS distribution, either alone or through intermediaries. However, cytosolic $\mathrm{Ca}^{2+}$ chelators do not prevent $P S$ redistribution in apoptotic cells, ${ }^{70}$ even though external application of EGTA does. $^{69,70}$ More recently, it has been shown that the genetic abnormality in Scott syndrome, which blocks scramblase activation by elevated cytosolic $\mathrm{Ca}^{2+}$, has no effect on scramblase activation during apoptosis ( $P$ Williamson et al., submitted), strongly suggesting that scramblase activation in apoptotic cells does not result from changes in cytosolic $\mathrm{Ca}^{2+}$ levels. Activation of the scramblase is not restricted to apoptotic cells, however, and occurs upon activation of lymphocytes, monocytes and neutrophils. $^{16}$ In both apoptotic and activated cells, the scramblase is activated upon activation of protein kinase $\mathrm{C} \delta$, although scramblase activation in activated cells is only transient and the translocase does not appear to be affected. ${ }^{71}$ Finally, studies with inhibitors suggest that scramblase activation requires polyamines, ${ }^{72}$ but why that should be the case is not clear.

Another obvious possible mechanism for regulating PS exposure is that the translocase and scramblase might be targets of proteolytic caspases activated during the autodigestion or execution phase of apoptosis. Indeed, redistribution of $P S$ is sensitive in some instances to the wide spectrum caspase inhibitor zVAD-fmk. ${ }^{73}$ However, it has also been shown that exposure of PS and subsequent phagocytosis of apoptotic cells can be inhibited while caspase activation remains normal, as measured by PARP cleavage and DNA degradation. ${ }^{74}$ Moreover, in instances when caspase activation is not required for the induction of apoptosis, PS exposure downstream is not sensitive to zVAD-fmk. ${ }^{69}$ Similarly, induction of apoptosis in sperm and avian erythroid cells results in DNA degradation, as measured by TUNEL-positive nuclei, PS exposure, and eventual cell lysis, but these processes do not appear to be caspase-dependent. ${ }^{75}$ In addition, at least in lymphocytes, application of EGTA to apoptotic cells can restore translocase activity and extinguish scramblase activity. ${ }^{69}$ These findings argue that the regulation of the translocase and scramblase can be reversible, making it unlikely that they are direct targets of caspases, and suggesting that PS exposure is one of several features of apoptosis which are independent of zVAD-sensitive caspases. Since protein kinase $\mathbf{C} \delta$ is cleaved and activated in a caspase 3dependent manner in apoptotic cells, ${ }^{71}$ zVAD-insensitivity of PS exposure suggests that mechanisms independent of protein kinase $\mathrm{C} \delta$ activation are available for activating the scramblase in apoptotic cells. However the translocase and scramblase are regulated, redistribution of PS appears to be downstream of participation by bcl-2, ${ }^{56}$ and analysis of APAF knockout mice suggests that PS exposure may be downstream of this ced-4 homolog as well. ${ }^{76}$ The fact that PS exposure is caspase-independent suggests that APAF may play a role in the regulation of pathways that are not connected to the activation of the zVAD-sensitive caspase$9 .^{77}$

\section{PS as a signal for phagocytosis of apoptotic cells}

The universality of PS exposure on apoptotic cells argues for an important role for loss of lipid asymmetry in apoptosis, but provides no real clues by itself as to what that role might be. Nor does it necessarily follow that PS exposure is the property 
of functional consequence, rather than just an indicator of loss of asymmetry, since a decrease in lipid order ${ }^{78}$ and packing, ${ }^{79}$ an increase in fluidity ${ }^{80}$ and an increase in hydrophobicity of the outer leaflet ${ }^{22}$ also accompany loss of asymmetry. However, there is now ample evidence that loss of asymmetry targets apoptotic cells for phagocytosis and that $\mathrm{PS}$ is a key element in this process.

As is the case for erythrocytes which have lost their asymmetric distribution of phospholipids, PS, either in the form of liposomes or just its water-soluble headgroup (phosphoserine), can stereospecifically inhibit phagocytosis of apoptotic cells. ${ }^{5}$ These data demonstrate (1) that PS is not just an indicator of loss of lipid asymmetry in apoptotic cells, but rather an active participant in phagocytosis, and (2) that a receptor protein is involved in the recognition of the PS headgroup. For some time, appreciation of the generality of the central role of PS in the phagocytosis of apoptotic cells was limited by the fact that only recognition by macrophages, such as elicited peritoneal macrophages, is inhibited by PS vesicles, while phagocytosis by unactivated macrophages, such as bone marrow or monocyte-derived macrophages, is not sensitive to these vesicles. ${ }^{81}$ This difference led to the supposition that macrophages possess either a PS-dependent or PSindependent $\left(\alpha_{v} \beta_{3}\right.$ integrin-independent) recognition system. However, lipid-symmetric erythrocytes (which display PS on their surface and whose phagocytosis is inhibited by PS vesicles) inhibit uptake of apoptotic cells by macrophages which use the $\alpha_{v} \beta_{3}$ integrin-dependent mechanism. $^{24}$ Furthermore, annexin blocks phagocytosis of apoptotic thymocytes by both types of macrophages, although it has no effect on or even enhances phagocytosis resulting from $\mathrm{Fc}$ receptor recognition. ${ }^{82}$ These results imply that PS recognition is an integral part of the removal of apoptotic cells by all macrophages.

In the literature, macrophages which utilize the $\alpha_{v} \beta_{3}$ integrin system for apoptotic cell recognition have been described as 'unactivated' macrophages and those which are inhibitable by PS vesicles as 'activated' macrophages. This usage is unfortunate because the term 'activation' also refers to macrophages which have become cytocidal. Until a more appropriate terminology is agreed upon and adopted, the terms activated and unactivated will continue to be used. They are used in the remainder of this review with the understanding that they refer only to the alternate systems used by macrophages to recognize apoptotic cells.

Remarkably, it has recently been shown that exposure of $\mathrm{PS}$ is not just required on the apoptotic cell. Over a decade ago, studies with fluorescent membrane probe MC540 suggested that macrophages constitutively express lipidsymmetric domains in the plasma membrane which preferentially cycle into endocytic vesicles. ${ }^{83}$ Recently, in vivo annexin labeling revealed that the macrophage membrane near or surrounding the engulfed apoptotic cell exposes PS like the apoptotic cell itself. ${ }^{67}$ This PS exposed on the phagocyte surface is required in the phagocytosis process, since treating macrophages with annexin is as effective as treating apoptotic lymphocytes in blocking the engulfment process. ${ }^{84}$ The engulfment process thus seems to require interactions between PS-exposing membranes on both the engulfing and target cells, interactions that are not required for engulfment of other, non-PS-exposing particles by the same phagocytes.

If $P S$ recognition is important, something, and presumably a protein, must do the recognizing. Recently, Fadok and coworkers ${ }^{85}$ have identified a protein molecule required for phagocytosis of apoptotic cells by activated macrophages, which are those sensitive to PS vesicles. This molecule is expressed only at low levels on unactivated macrophages, and its expression on transfected cells renders phagocytosis by those cells sensitive to PS vesicles. Together, these results imply that the molecule is intimately involved in the PS-dependent mechanism of phagocytosis by activated macrophages, and the authors suggest that it may be a receptor for PS. If this exciting possibility is true, the molecule cannot be the only such receptor molecule, since it is apparently not required for the PS-dependent recognition of apoptotic cells by unactivated macrophges, and is presumably not generally present on the target cell surface, which may also possess molecules which recognize the PS on the macrophage surface. Whether a family of these molecules may play similar roles on different cells is an interesting question.

\section{Surface receptors and the engulfment of apoptotic cells}

Although PS exposure is central to the recognition of apoptotic lymphocytes by all types of macrophages, the preceding discussion has already hinted that membrane proteins are also required. A great deal of energy has been expended in identifying the proteins that participate in the phagocytosis of apoptotic cells, an effort which has resulted in an embarrassment of riches (Table 1). Several principles are useful in clarifying the profusion and confusion represented by the (growing) size of this table. One is that the involvement of

Table 1 Proteins implicated in the recognition of apoptotic cells

\begin{tabular}{|c|c|c|c|}
\hline Protein & Cell & Evidence & Reference \\
\hline \multicolumn{4}{|l|}{ Integrins } \\
\hline$\alpha_{\mathrm{v}} \beta_{3}$ & Phagocyte & Biochem & 81 \\
\hline$\alpha_{v} \beta_{5}$ & & " & 86 \\
\hline$\alpha_{?} \beta_{1}$ & " & " & 162 \\
\hline \multicolumn{4}{|l|}{ Scavenger receptors } \\
\hline CD36 & Phagocyte & Biochem & 88 \\
\hline OxLDL & " & " & 163 \\
\hline SRBI & " & " & 89 \\
\hline SR-A & " & " & 164 \\
\hline Croquemort & " & Genetic & 165 \\
\hline Asialoglycoprotein receptor & Phagocyte & Biochem & 166 \\
\hline Lectin-like receptor & Phagocyte & Biochem & 167 \\
\hline CD14 & Phagocyte & Biochem & 95 \\
\hline ICAM3 & Target & Biochem & 87 \\
\hline $\mathrm{ABC} 1$ & Both & Gen/Biochem & 113 \\
\hline ced-7 & Both & Genetic & 108 \\
\hline ced-5 & Phagocyte & Genetic & 168 \\
\hline ced-6 & Phagocyte & Genetic & 103 \\
\hline Complement proteins & - & Biochem & $169-171$ \\
\hline Thrombospondin & - & Biochem & 88 \\
\hline$\beta 2$-GPI & - & Biochem & 160 \\
\hline Gas-6 & - & Biochem & 172 \\
\hline
\end{tabular}


many of these proteins is not general, but rather is restricted to particular target/phagocyte pairs. Thus, recognition involving the lectin-like receptor is specific to activated macrophages, the $\alpha_{v} \beta_{3}$ integrin to unactivated macrophages, the $\alpha_{v} \beta_{5}$ integrin to naive dendritic cells. While such proteins may play roles in more than one cell system, they are clearly not general; whether they are functional substitutes for each other is not known, although in some cases, such as the integrins, this conclusion is tempting.

A second principle is that engulfment must involve cooperation among receptors (Table 2). For example, the phagocytosis of simple lipid-symmetric erythrocytes or apoptotic lymphocytes by activated macrophages involves a PS receptor, because it is partially inhibited by PS vesicles, and also a lectin-like receptor, because it is also partially inhibited by $\mathrm{N}$-acetylglucosamine (GlcNAc). ${ }^{24}$ The inhibition by PS vesicles and GIcNAc are not additive, suggesting that the two receptors must cooperate. Similarly, engulfment of apoptotic lymphocytes by unactivated macrophages is partially inhibited by RGDS, which is not additive with the inhibition provided by lipidsymmetric erythrocytes. These results suggest that multiple signals combine on the apoptotic cell surface to produce a complex ligand recognized by a complex of receptors. $^{24}$

With these principles in mind, several patterns can be observed in Table 1. The first is the repeated identification of integrins, including the $\alpha_{\mathrm{v}} \beta_{3}{ }^{81}$ or $\alpha_{\mathrm{v}} \beta_{5}{ }^{86}$ receptors, or integrin ligands such as ICAM-3, the only protein on the apoptotic cell surface identified as involved in recognition. ${ }^{87}$ As yet an integrin has not been identified in the recognition of apoptotic cells by activated macrophages, and the general integrin-inhibitory peptide RGDS has no effect on recognition by these cells, but not all integrin binding is sensitive to the inhibitor, leaving open the question of whether the requirement for integrin involvement is general.

A second regularity is the repeated identification of members of the scavenger receptor family, including CD36 in conjunction with thrombospondin, ${ }^{88} \mathrm{SR}-\mathrm{BI},{ }^{89}$ and the product of the croquemort gene in Drosophila. ${ }^{90}$ Since these proteins recognize polyanions, including phospholipid micelles and bilayers containing anionic phospholipids such as $\mathrm{PS},{ }^{91}$ they might be capable of recognizing $\mathrm{PS}$ on the apoptotic cell surface and contribute to phagocytosis to a varying degree depending on the nature of the target cell

Table 2 Receptors implicated by inhibitors in recognition of apoptotic lymphocytes by macrophages

\begin{tabular}{lccl}
\hline & \multicolumn{3}{c}{ Macrophage inhibited } \\
Inhibitor & Unactivated & Activated & Implied receptor \\
\hline PS vesicles & No & Yes & PS receptor I \\
LS erythrocytes & Yes & No & PS receptor II (?) \\
RGDS, $\alpha_{v} \beta_{3}$ Ab & Yes & No & $\alpha_{v} \beta_{3}$ integrin \\
GIcNAc & No & Yes & Lectin-like receptor \\
61D3 Mab & Yes & Yes & CD14 (LPS receptor) \\
Annexin V & Yes & Yes & PS receptors on apoptotic \\
CD36 Ab & Yes & Yes & $\begin{array}{c}\text { CD36 (scavenger } \\
\text { receptor) }\end{array}$ \\
& & & recer macrophage \\
\hline
\end{tabular}

and phagocyte. However, they cannot account for instances where PS has been shown to be the only anionic lipid which inhibits phagocytosis of apoptotic cells nor explain the stereospecificity of PS inhibition. These considerations and others, including indirect evidence regarding CD36 in particular, argue that the PS receptor is not a scavenger receptor. ${ }^{92}$ However, whether these receptors contribute to nonspecific recognition of the anionic surface of a PS-exposing apoptotic cell membrane remains an open question. Moreover, while removal of apoptotic cells is not measurably reduced in mice in which scavenger receptor genes have been (singly) disabled by knockout mutations, ${ }^{93}$ apoptotic cell removal in Drosophila is specifically sensitive to mutation of the croquemort gene, ${ }^{90}$ suggesting that these receptors play some central and important part in the process. CD14 is a macrophagespecific receptor which binds lipopolysaccharide (LPS), triggering inflammatory responses and septic shock. ${ }^{94}$ It was identified by expression cloning as the target of the monoclonal antibody 61D3, ${ }^{95}$ which blocks phagocytosis of lymphocytes by both activated and unactivated macrophages. $^{24,96}$ Only anti-CD14 antibodies which inhibit binding of LPS can block phagocytosis of apoptotic lymphocytes, suggesting that the LPS and apoptotic cell binding sites are closely associated or identical. ${ }^{95}$ Moreover, phagocytosis of lipid-symmetric erythrocytes is CD14dependent. ${ }^{24,97}$ Since the only property which lipidsymmetric erythrocytes are known to share with apoptotic thymocytes is exposure of PS on their cell surface, these observations suggest that CD14 may recognize PS. However, there is no evidence in support of this possibility other than a report that human monocyte THP-1 cells transfected with CD14 display a twofold increase in low affinity binding of PS vesicles in the presence of LPSbinding protein. ${ }^{98}$

\section{Activation of protein receptors for apoptotic cells}

Work from Raff's laboratory 99,100 has shown that all the components necessary for initiation and completion of the apoptotic process pre-exist in the cytoplasm of mammalian cells: synthesis of new proteins is not required for cells to enter and complete the process of apoptosis. Although the cell surface changes which lead to phagocytosis occur early in apoptosis, there is still plenty of opportunity within that timeframe for the modification, removal, and reassortment of cell surface molecules in the service of engulfment. Nevertheless, the fact that the process does not require novel gene expression, combined with the large variety of cell types and environments in which recognition and phagocytosis take place, raises the possibility that the interaction between the apoptotic cell and phagocyte may not depend on dedicated receptor/ligand interactions, but rather may make opportunistic use of the particular cell surface recognition molecules that are available on the target cell and its neighbor before apoptosis begins. This possibility would explain the familiarity of many of the molecules which have been suggested as participants. It would also predict that the proteins involved would differ depending on the specific cells which are 
interacting as target and phagocyte. Exactly such differences have been demonstrated when the same target is presented to different kinds of engulfing macrophages ${ }^{24}$ and when different targets are presented to the same macrophage $(Y$ Ren et al., submitted).

In this view, the nature of the specific ligands and receptors involved becomes a problem which is specific to the particular cells under study. If this view is correct, the current list of cell surface receptors involved in recognition may actually be limited by the small number of target/ phagocyte cell pairs which have been examined (largely macrophages and apoptotic hematopoietic cells), and this list may be considerably lengthened as other combinations are studied. The more general question is then the mechanism by which these interactions are usurped by apoptosis for the purpose of recognition and phagocytosis of apoptotic cells, processes not provoked when these receptors and ligands normally interact. Accumulating evidence suggests that the critical activating process on the apoptotic target cell surface is the transbilayer rearrangement of membrane lipids.

When the scramblase is activated in erythrocytes by raising cytosolic $\mathrm{Ca}^{2+}$ concentrations, the resulting lipidsymmetric erythrocytes are recognized and phagocytosed by macrophages by a process which involves CD14 ${ }^{24}$ and, in the case of activated macrophages, lectin-like receptors, ${ }^{97}$ just as in the case of apoptotic targets. Yet the absence of a nucleus, protein synthesis apparatus, or internal membrane system in erythrocytes precludes the appearance of new proteins on the cell surface. In this model system, integrin receptors do not seem to play a role, but when lipid asymmetry is similarly abolished in more complex lymphocytes by raising cytosolic $\mathrm{Ca}^{2+}$ concentrations, the cells immediately become targets for recognition by the same CD14 receptor, lectin-like receptor, and integrin-based mechanisms that are involved in recognition of authentic apoptotic cells. ${ }^{84}$ On the other hand, apoptotic cells in which PS exposure is blocked or defective are no longer recognized by any of the proteinmediated mechanisms. ${ }^{101}$ Together, these results argue that loss of phospholipid asymmetry and/or the appearance of PS on the apoptotic cell surface activate the recognition process, including those features which are dependent on specific membrane protein receptors and ligands other than PS. As mentioned above, alterations in membrane physical properties accompany transbilayer lipid rearrangement; in the apoptotic lymphocyte membrane, any of these changes may promote the generation of recognition ligands through the lateral rearrangement and association of existing membrane proteins, formation of PS-protein complexes or the exposure of new epitopes on proteins. ${ }^{102}$

\section{Other proteins implicated in phagocytosis}

The list of proteins implicated in phagocytosis of apoptotic cells is not restricted to cell surface molecules. In particular, genes identified as required for removal of apoptotic cells in $C$. elegans encode several proteins which are not cell surface receptors. One of these, the product of the ced- 6 gene, ${ }^{103}$ is a cytoplasmic protein which has been proposed to act as an adaptor in a signal transduction pathway. The nature of this pathway is currently obscure, but it is clear that a signaling pathway must be activated during removal of apoptotic cells. This pathway suppresses the normal inflammatory responses of macrophages to phagocytic stimuli ${ }^{95,104}$ through autocrine/ paracrine mechanisms involving TGF-beta, PGE2 and PAF. ${ }^{105}$ When in the phagocytic process this pathway is provoked, whether it involves ced- 6 homologs, and whether its induction involves a receptor/ligand interaction separate from those involved in binding and recognition of the apoptotic cell, are all currently unknown.

Two other proteins, the products of the ced-5 and ced-10 loci, are required for removal of apoptotic cells in $C$. elegans. These proteins are members of the crkll/dock180 signaling pathway; ${ }^{106}$ in mammalian cells, this pathway is linked to motility, and closely related pathways play important roles in controlling the cytoskeletal rearrangement required for engulfment. ${ }^{107}$ These findings confirm the conclusion drawn from the specificity of annexin inhibition of phagocytosis and the specificity of anti-phlogistic effects that engulfment of apoptotic cells is mechanistically distinct from the phagocytosis of other targets. Like those studies, information on how the process differs is only sketchy at this time, and it is not yet clear how the unique events on the cell surface are linked to the unique anti-phlogistic pathway or the unique pathway regulating the cytoskeletal machinery.

Another molecule identified from the collection of $C$. elegans engulfment mutants is the product of the ced-7 gene, ${ }^{108}$ a member of a very large family of membrane ATPases called ABC proteins. ${ }^{109}$ Other members of this family include the regulatory subunit of the SUR $\mathrm{K}^{+}$ transporter, ${ }^{110}$ the CFTR protein mutated in cystic fibrosis, ${ }^{111}$ and the mdr and MRP proteins whose overexpression confers non-specific drug resistance on cells. ${ }^{112}$ A human homolog of the ced-7 gene, called $A B C 1$, was isolated from macrophages, and a functional homology between the worm and human proteins established by demonstration that intracellular injection of antibodies against $A B C 1$ into macrophages blocked engulfment of apoptotic cells. ${ }^{113} \mathrm{~A}$ knockout mutation of this gene in mice also resulted in a block to the rapid engulfment of apoptotic cells by macrophages. ${ }^{114}$ Remarkably, in C. elegans, the product of the ced-7 gene was equally required in both the target and the phagocytic cell, ${ }^{108}$ and pharmacological inhibition of $A B C 1$ indicates that the same is true in mammals. ${ }^{115}$ The similarity of this dual requirement to that for PS exposure seems to be no mere coincidence-the same pharmacological inhibitors that suppress engulfment also block $\mathrm{Ca}^{2+}$-induced loss of lipid asymmetry and PS exposure in both targets and macrophages, ${ }^{115}$ and PS exposure is also abnormal in lymphocytes and erythrocytes from $A B C 1$ knockout mice. ${ }^{114}$

In a surprising turn of events, the phenotype of the human knockout of the $A B C 1$ gene is also known since the discovery that mutations in this gene are responsible for Tangier disease, ${ }^{116-121}$, a genetic deficit of interest because patients display a defect in reverse cholesterol transport from cells to circulating lipoproteins. This phenotype is not peculiar to humans-the ABC1 knockout 
mouse displays a similar defect. ${ }^{114}$ These findings imply that $A B C 1$ plays an important role in the process of cholesterol efflux. This process is not well understood, so that the participation of $A B C 1$ does not cast any light on how $A B C 1$ might affect this process. The hydrophobic character of cholesterol makes it unlikely that any molecule is required for its transbilayer transport; a more likely role for $A B C 1$ may be that it contributes to the phospholipid efflux which occurs concomitantly with cholesterol efflux, ${ }^{122}$ but experimental evidence will be needed to settle this issue. What is intriguing is the connection that is revealed between recognition of apoptotic cells and lipid transport processes; the same intriguing connection can be drawn from the involvement of lipoprotein-binding scavenger receptors in apoptotic cell phagocytosis.

\section{Professional vs non-professional phagocytes}

It should be kept in mind in all these considerations that cell removal requires at least two distinct mechanistic steps. The first is recognition of the apoptotic cell, i.e., the formation of cell-cell interactions specific to the apoptotic nature of the target cell. The second is the actual engulfment process, which must depend on the identification of the first interaction as apoptosis-specific. The large majority of studies on the mechanisms of phagocytosis of apoptotic cells have employed professional phagocytes (macrophages), where these two processes are closely linked to one another in time, with phagocytosis following recognition within a few minutes. ${ }^{123}$ Under these circumstances, specific phagocyte/ target pairs which have not yet completed engulfment are rare $^{24}$ and difficult to quantify separately. But these mechanisms are in fact separable. Resident peritoneal macrophages specifically bind but do not engulf PS-exposing erythrocytes unless activated ${ }^{124}$ or unless serum is present. $^{125}$ Even more clearly, engulfment by nonprofessional phagocytes such as $\mathrm{BHK}$ cells begins with a rapid recognition step, but phagocytosis is delayed for several hours. ${ }^{123}$ While the characteristics of these individual steps are not yet known, the fact that annexin inhibits the phagocytosis of apoptotic smooth muscle cells by their non-professional normal neighbors ${ }^{57}$ implies that the involvement of PS in phagocytosis is not specific to professional phagocytes.

Overall, it might be expected that the recognition and binding step is primarily a matter of specific receptor-ligand interactions, while the engulfment step is a matter of membrane and cytoskeletal dynamics and the two are presumably linked by signaling events of some kind. But certainly some of the mechanisms uncovered by studies of macrophages are specific to these specialized cells and not generally applicable to non-professional phagocytes. For example, although CD14 appears to be absolutely required by professional phagocytes of all stripes to phagocytose apoptotic lymphoid cells, this requirement cannot extend to non-professional phagocytes since expression of CD14 is restricted to cells of the monocyte/macrophage lineage. While some unknown protein more ubiquitously expressed may play a role in non-professional cells similar to the role of CD14 in professional cells, CD14 must represent a specialization of professional phagocytes for removal of apoptotic cells, particularly in the immune system. The same logic applies to any of the other surface molecules implicated in phagocytosis-to the extent that they are restricted to professional phagocytes, there must be a functional homolog in other types of cells if the process in which they participate is general to phagocytosis of apoptotic cells. On the other hand, since apoptotic cells of all types express PS on their surface, and presumably undergo the physical membrane changes accompanying loss of asymmetry, the ligands on apoptotic cells recognized by non-professional phagocytes may be generated by the same mechanisms as the ligands recognized by professional phagocytes, though, as discussed above, the actual ligand/receptor pairs may vary depending on the cell types. A key to unraveling the roles of the many molecules which participate in apoptotic cell clearance without provoking inflammation may lie in distinguishing the several steps in the process and identifying the molecules required for each of them.

\section{Other consequences of PS exposure}

As mentioned above, apoptosis, and the exposure of PS associated with it, are probably over 600 million years old. Given that every cell in the body has the ability to sequester PS to the inner leaflet or to present it on the cell surface, it is not surprising that over time this process has been appropriated by evolution for specialized purposes. As a result, there are several physiological processes in which PS exposure plays a role, which in turn provide a source for pathological consequences if disrupted by disease. A consideration of these specialized instances may provide insights into the ancestral mechanisms which regulate PS exposure and recognition.

The best studied of these specialized systems is the platelet. When the platelet is activated by thrombin and collagen acting through the $\alpha \mathrm{ll} \beta 1$ and gpVI receptors, the translocase is inactivated and a vigorous scramblase is activated, ${ }^{126}$ bringing $P S$ extremely rapidly (seconds) to the platelet surface. ${ }^{127}$ The exposed PS becomes the site of assembly of the tenase and prothrombinase complexes of the proteolytic cascade leading to the thrombin cleavage of fibrinogen and formation of the fibrin matrix of the clot. ${ }^{128}$ Both the tenase and prothrombinase complexes consist of a catalytic subunit and a cofactor; while each of these can stereospecifically bind PS by itself, ${ }^{129-131}$ the enzymatic activity of the complex is much higher than that of either protein alone. ${ }^{132}$ The PS-binding region of the catalytic subunits (factors IXa and Xa) consist of characteristic Gla domains which contain several $\gamma$-carboxyglutamic acid residues, a vitamin- $K$ dependent amino acid modification. $^{133}$ The cofactor subunits (factors Va and VIIla) do not contain such residues, but are even more specific than the catalytic subunits in their recognition of PS. ${ }^{134}$ This cooperative 'recognition' mechanism may represent a strategy for obtaining highly specific recognition of a ligand such as PS which is structurally simple, but repetitively expressed. It is also superficially reminiscent of the proposal that PS-dependent recognition of apoptotic cells 
requires a complex, multicomponent recognition system. More concretely, these proteins contain domains which recognize $\mathrm{PS}$, and their PS-binding domains appear in other proteins which recognize $P S$ in the more primitive process of clearing apoptotic cells. Although macrophages may be involved in resolution of the clot through recognition and phagocytosis of activated platelets with PS on their surface, such a process is secondary to the more important, crucial role of PS in clot formation.

Besides these possible correlates of PS recognition on apoptotic cells, platelets might also illuminate the signaling mechanisms which regulate PS exposure. As in apoptotic cells, PS exposure in platelets requires coordinate regulation of the translocase and scramblase. At present, regulation of these processes is not well understood in either system, but a natural mutation which prevents activation of the scramblase is manifest in Scott syndrome. ${ }^{136,137}$ Since the translocase is regulated normally in the cells of Scott syndrome patients, ${ }^{137}$ it and the scramblase appear to be regulated independently of one another. The scramblase in normal platelets is activated by a $\mathrm{Ca}^{2+}$-mediated signaling pathway which fails to activate the scramblase in Scott platelets. Artificially elevating $\mathrm{Ca}^{2+}$ using ionophore similarly fails to activate the scramblase in Scott platelets, erythrocytes and lymphocytes. ${ }^{138,139}$ But activation of the scramblase in apoptotic Scott lymphocytes proceeds normally, implying that the physiological $\mathrm{Ca}^{2+}$ signaling pathway utilized by activated platelets is not the pathway used by apoptotic lymphocytes ( $P$ Williamson et al., submitted).

As mentioned above, the studies of Van den Eijnde ${ }^{62}$ quite surprisingly reveal that PS exposure occurs on budding megakaryocytes of mouse embryos, as well as on fusing myoblasts, confirming an old report that PS is exposed on myoblasts fusing in culture. ${ }^{140}$ The functional significance of PS exposure in these two cases is not clear, although extensive membrane fusion is a critical feature of both myotube formation and thrombocyte release from megakaryocytes, and PS has long been implicated in the fusion process. ${ }^{83}$ Similarly, it is reasonable to suppose that the mechanism of PS exposure in these two cell types is derived in some way from the more ancestral mechanism in apoptotic cells. Most importantly, however, the presence and persistence of these PS-exposing cells in the normal embryo is evidence that PS exposure is not sufficient by itself to trigger phagocytosis. Whether these cells escape phagocytosis because they lack some other important component required for recognition, because they somehow mask the exposed PS on their surface, or because they occupy some privileged site within the embryo devoid of competent phagocytes will be an interesting subject for further investigation.

Erythryopoiesis provides an instructive instance in which localized exposure of PS on the apoptotic cell surface may result in a specialized phagocytic event. In mammals, the development of the nucleated erythroblast comes to a climax upon enucleation, during which the cytoplasm of the polychromatophilic erythroblast becomes the incipient reticulocyte, as the nucleus extrudes from the erythroblast surrounded by only a thin cytoplasmic remnant and is engulfed by a macrophage even before segregation of the two bodies is complete. ${ }^{141,142}$ When observed in isolation, the process of enucleation was described by Bessis: 'With time lapse photography ..., the cell appears to push pseudopodia frenetically in all directions and after a number of apparent convulsions, the nucleus is extruded', ${ }^{143}$ a description which is highly reminiscent of the morphological description of apoptosis by Parnaik. ${ }^{123}$ Moreover, the nuclear condensation and margination that occurs during this process are quite similar to the morphology of apoptotic cells. The portion of the plasma membrane which surrounds the lobe of the cell containing the extruding nucleus binds MC540, ${ }^{144145}$ a fluorescent dye which marks lipid-symmetric membranes ${ }^{79}$ and stains apoptotic cells, ${ }^{5,55}$ suggesting that recognition and engulfment of this portion of the erythroblast occurs by the same PS-dependent mechanisms by which apoptotic cells are recognized and phagocytosed. Remarkably, the reticulocyte lobe of the cell does not bind MC540, and is not phagocytosed, but rather after partition is complete is released into the circulation. How this portion of the membrane escapes losing lipid asymmetry is not known, but it may depend on lateral rearrangement and localization, within the plane of the membrane, of the critical proteins which control lipid asymmetry. In humans, the erythrocytes which mature from the incipient reticulocyte contain very low levels of scramblase compared to platelets and lymphocytes, ${ }^{47,146}$ and pig erythrocytes lack scramblase activity altogether, ${ }^{147}$ while translocase levels in both species of erythrocytes are respectable. How lateral rearrangement and segregation of the scramblase to the plasma membrane surrounding the extruding nucleus might occur is certainly not clear, but may be related to the compartmentalization of the erythrocyte spectrin-based cytoskeleton to the reticulocyte portion of the enucleating cell. $^{148}$

Given the potent responses to PS exposed on the surface of platelets and apoptotic cells, it is not surprising that inappropriate exposure of PS can have pathological consequences. Abnormal PS exposure has been associated with sickle cell disease for many years. One source of this exposure is the release of small vesicles from sickle erythrocytes; ${ }^{149,150}$ these vesicles become lipid symmetric, ${ }^{151}$ perhaps because of ATP depletion arising from their high surface/volume ratios or perhaps during the fusion process by which they are released. In addition, it has become clear that PS exposure also occurs in a small fraction of circulating sickle cells ${ }^{152,153}$ which may contribute to the anemia as well as the hypercoaguability ${ }^{154}$ associated with the disease. Because human erythrocytes contain both translocase and scramblase activities, the exposure of PS must require translocase inactivation and may also involve scramblase activation. One possible mechanism for PS exposure in sickle erythrocytes might be the release of $\mathrm{Ca}^{2+}$ from internal vesicles contained within sickle erythrocytes ${ }^{155}$ which originate from the plasma membrane and thus concentrate $\mathrm{Ca}^{2+}$ inside themselves by the action of the plasma membrane $\mathrm{Ca}^{2+}$. ATPase. ${ }^{156}$ Sporadic lysis and release of high concentrations of $\mathrm{Ca}^{2+}$ from the vesicles might account for the 
appearance of PS on only a small fraction of circulating cells.

One intriguing finding which may be related to the exposure of PS on sickle erythrocytes is that sickle cell disease patients tend to develop antiphospholipid antibodies (aPLA). ${ }^{154}$ These autoimmune antibodies are better known from studies of patients with aPLA syndrome and lupus patients, where it has been established that the antibodies are actually low affinity antibodies directed against plasma proteins, including $\beta$-2 glycoprotein I, thrombin, and proteins $S$ and $C .{ }^{157}$ The antibodies were originally thought to react with phospholipids because they bind to ELISA plates coated with phospholipids. It is now clear that this behavior results from the ability of the plates to bind and concentrate the protein 'cofactors' which are the actual target of the antibodies. ${ }^{158}$ The appearance of the 'aPLA' in patients with sickle cell disease, where the pathological appearance of PS is well documented, lends weight to the proposal that the antibodies may arise generally from the abnormal persistence of PS-exposing cell surfaces. A more general source for such surfaces might be from delay or failure in the system of apoptotic cell removal. $^{159}$ The resulting persistence of PS-exposing apoptotic cells could permit accumulation of cofactors on the cell surface, thus generating the provoking autoantigens. An important ramification may be the effect on recognition of apoptotic cells coated with these proteins. Because of its ability to bind PS, the major cofactor, $\beta$-2 glycoprotein I, has been proposed as a marker for apoptotic cells. ${ }^{160}$ The presence of $\beta-2$ glycoprotein I does not enhance the efficiency of recognition of apoptotic cells by macrophages, ${ }^{161}$ arguing against such a role for the protein in normal recognition of apoptotic cells. However, the aPLA which recognize and bind to $\beta-2$ glycoprotein on the cell surface do enhance the phagocytosis of apoptotic cells through Fc-mediated phagocytosis; ${ }^{161}$ under such circumstances, phagocytosis of apoptotic cells results in a proinflammatory response by the phagocytic cells. Thus, aPLA may convert the removal of apoptotic cells from a benign, physiological to a pathological process.

Together, these results point out how failure to remove apoptotic cells in a timely fashion may have pathological consequences in addition to the local inflammation which is usually invoked as the physiological rationale for rapid removal of apoptotic cells. Whether such a failure is a contributor to autoimmune diseases such as lupus, and if so, where the breakdown in removal occurs, will be important areas for studies exploring the clinical implications resulting when removal of apoptotic cells is compromised.

\section{References}

1. Rayner JC and Pelham HRB (1997) Transmembrane domain-dependent sorting of proteins to the ER and plasma membrane in yeast. EMBO J. 16 : 1832- 1841

2. Varma R and Mayor S (1998) GPI-anchored proteins are organized in submicron domains at the cell surface. Nature 394: 798-801

3. Friedrichson T and Kurzchalia TV (1998) Microdomains of GPI-anchored proteins in living cells revealed by crosslinking. Nature 394: 802-805
4. Rietveld A and Simons K (1998) The differential miscibility of lipids as the basis for the formation of functional membrane rafts. Biochim. Biophys. Acta 1376: 467-479

5. Fadok VA, Voelker DR, Campbell PA, Cohen JJ, Bratton DL and Henson PM (1992) Exposure of phosphatidylserine on the surface of apoptotic lymphocytes triggers specific recognition and removal by macrophages. J. Immunol. 148: 2207-2216

6. Nakamura M, Yagi H, Kayaba S, Ishii T, Ohtsu S, Gotoh T and Itoh T (1995) Most thymocytes die in the absence of DNA fragmentation. Arch. Histol. Cytol. 58: $249-256$

7. Nakamura M, Yagi H, Ishii T, Kayaba S, Soga H, Gotoh T, Ohtsu S, Ogata Mand Itoh T (1997) DNA fragmentation is not the primary event in glucocorticoidinduced thymocyte death in vivo. Eur. J. Immunol. 27: 999-1004

8. Ellis RE, Jacobson DM and Horvitz HR (1991) Genes required for the engulfment of cell corpses during programmed cell death in Caenorhabditis elegans. Genetics 129: 79-94

9. Allen TM, Williamson P and Schlegel RA (1998) Phosphatidylserine as a determinant of reticuloendothelial recognition of liposome models of the erythrocyte surface. Proc. Natl. Acad. Sci. USA 85: 8067-8071

10. Schroit AJ and Fidler IJ (1982) Effects of liposome structure and lipid composition on the activation of the tumoricidal properties of macrophages by liposomes containing muramyl dipeptide. Cancer Res. 42: 161-167

11. Nishikawa K, Arai H and Inoue K (1990) Scavenger receptor-mediated uptake and metabolism of lipid vesicles containing acidic phospholipids by mouse peritoneal macrophages. J. Biol. Chem. 265: 5226-5231

12. Allen TM, Austin GA, Chonn A, Lin L and Lee KC (1991) Uptake of liposomes by cultured mouse bone marrow macrophages: influence of liposomes composition and size. Biochim. Biophys. Acta 1061: 56-64

13. Lee KD, Hong K and Papahadjopoulos D (1992) Recognition of liposomes by cells - in vitro binding and endocytosis mediated by specific lipid headgroups and surface charge density. Biochim. Biophys. Acta 1103: 185-197

14. Lee KD, Nir S and Papahadjopoulos D (1993) Quantitative analysis of liposome-cell interactions in vitro-rate constants of binding and endocytosis with suspension and adherent J774-cells and human monocytes. Biochemistry 32: $889-899$

15. Pradhan D, Williamson $P$ and Schlegel RA (1994) Phosphatidylserine vesicles inhibit phagocytosis of erythrocytes with a symmetric transbilayer distribution of phospholipids. Mol. Membr. Biol. 11: $181-187$

16. McEvoy L, Schlegel RA, Williamson P and Del Buono BJ (1988) Merocyanine 540 as a flow cytometric probe of membrane lipid organization in leukocytes. J. Leuk. Biol. 44: 337-344

17. Williamson P and Schlegel RA (1994) Back and forth: The regulation and function of transbilayer phospholipid movement in eukaryotic cells. Mol. Membr. Biol. 11: 199-216

18. Tait JF, Smith C and Wood BL (1999) Measurement of phosphatidylserine exposure in leukocytes and platelets by whole-blood flow cytometry with annexin V. Blood Cells Mol. Dis. 25: 271-278

19. Schroit AJ, Madsen JW and Tanaka Y (1985) In vivo recognition and clearance of red blood cells containing phosphatidylserine in their plasma membranes. J. Biol. Chem. 260: 5131-5138

20. Schlegel RA, Lumley-Sapanski K and Williamson P (1992) Single cell analysis of factors increasing the survival of resealed erythrocytes in the circulation of mice. Adv. Exp. Med. Biol. 326: 133-138

21. Tanaka Y and Schroit AJ (1983) Insertion of fluorescent phosphatidylserine into the plasma membrane of red blood cells. Recognition by autologous macrophages. J. Biol. Chem. 258: 11335-11343

22. McEvoy L, Williamson P and Schlegel RA (1986) Membrane phospholipid asymmetry as a determinant of erythrocyte recognition by macrophages. Proc. Natl. Acad. Sci. USA 83: 3311-3315

23. Pradhan D, Williamson $P$ and Schlegel RA (1994) Phosphatidylserine vesicles inhibit phagocytosis of erythrocytes with a symmetric transbilayer distribution of phospholipids. Mol. Membr. Biol. 11: $181-187$

24. Pradhan D, Krahling S, Williamson P and Schlegel RA (1997) Multiple systems for recognition of apoptotic lymphocytes by macrophages. Mol. Biol. Cell 8 : $767-778$

25. Boas FE, Forman L and Beutler E (1998) Phosphatidlyserine exposure and red cell viability in red cell aging and in hemolytic anemia. Proc. Natl. Acad. Sci. USA 95: $3077-3081$ 
26. Del Buono BJ, Williamson PL and Schlegel RA (1986) Alterations in plasma membrane lipid organization during lymphocyte differentiation. J. Cell Physiol. 126: $379-388$

27. Del Buono BJ, White SM, Williamson PL and Schlegel RA (1989) Plasma membrane lipid organization and the adherence of differentiating lymphocytes to macrophages. J. Cell Physiol. 138: 61-69

28. Schlegel RA, Stevens M, Lumley-Sapanski K and Williamson P (1993) Altered lipid packing identifies apoptotic thymocytes. Immunol. Lett. 36: 283-288

29. Schlegel RA and Williamson P (1987) Membrane phospholipid organization as a determinant of blood cell-reticuloendothelial cell interactions. J. Cell. Physiol. 132: $381-384$

30. Bretscher MS (1972) Asymmetrical lipid bilayer structure for biological membranes. Nature New Biol. 236: 11-12

31. Seigneuret M and Devaux PF (1984) ATP-dependent asymmetric distribution of spin-labeled phospholipids in the erythrocyte membrane: relation to shape changes. Proc. Natl. Acad. Sci. USA 81: 3751-3755

32. Zachowski A, Henry JP and Devaux PF (1989) Control of transmembrane lipid asymmetry in chromaffin granules by an ATP-dependent protein. Nature 340 : $75-76$

33. Zachowski A and Gaudry-Talarmin YM (1990) Phospholipid transverse diffusion in synaptosomes: evidence for the involvement of the aminophospholipid translocase. J. Neurochem. 55: 1352-1356

34. Morrot G, Zachowski A and Devaux PF (1990) Partial purification and characterization of the human erythrocyte Mg2(+)-ATPase. A candidate aminophospholipid translocase. FEBS Lett. 266: 29-32

35. Moriyama Y and Nelson N (1988) Purification and properties of a vanadate- and $\mathrm{N}$-ethylmaleimide-sensitive ATPase from chromaffin granule membranes. J. Biol. Chem. 263: 8521-8527

36. Hicks BW and Parsons SM (1992) Characterization of the P-Type and V-Type ATPases of cholinergic synaptic vesicles and coupling of nucleotide hydrolysis to acetylcholine transport. J. Neurochem. 58: 1211-1220

37. Tang XJ, Halleck MS, Schlegel RA and Williamson P (1996) A subfamily of Ptype ATPases with aminophospholipid transporting activity. Science 272 : 1495- 1497

38. Halleck MS, Pradhan D, Blackman C, Berkes C, Williamson P and Schlegel RA (1998) Multiple members of a third subfamily of P-type ATPases identified by genomic sequences and ESTs. Genome Res. 8: 354-361

39. Halleck MS, Lawler JF, Blackshaw S, Gao L, Nagarajan P, Hacker C, Pyle S, Newman JT, Nakanishi Y, Ando H, Weinstock D, Williamson P and Schlegel RA (1999) Differential expression of putative transbilayer amphipath transporters. Physiol. Genomics 1: 139-150

40. Bull LN, vanEijk MJT, Pawlikowska L, DeYoung JA, Juijn JA, Liao M, Klomp LWJ, Lomri N, Berger R, Scharschmidt BF, Knisley AS, Houwen RHJ and Freimer NB (1998) A gene encoding a P-type ATPase mutated in two forms of hereditary cholestasis. Nature Genetics 18: 219-224

41. van den Eijnde SM, Luijsterburg AJ, Boshart L, De Zeeuw Cl, van Dierendonck $\mathrm{JH}$, Reutelingsperger CP and Vermeij-Keers C (1997) In situ detection of apoptosis during embryogenesis with annexin $\mathrm{V}$ : from whole mount to ultrastructure. Cytometry 29: 313-320

42. van den Eijnde S, Boshart L, Baehrecke EH, de Zeeuw Cl, Reutelingsperger CPM and Vermeij-Keers C (1998) Cell surface exposure of phosphatidylserine during apoptosis is phylogenetically conserved. Apoptosis 3: 9-16

43. Williamson P, Algarin L, Bateman J, Choe HR and Schlegel RA (1985) Phospholipid asymmetry in human erythrocyte ghosts. J. Cell Physiol. 123: 209-214

44. Comfurius P, Senden JM, Tilly RH, Schroit AJ, Bevers EM and Zwaal RF (1990) Loss of membrane phospholipid asymmetry in platelets and red cells may be associated with calcium-induced shedding of plasma membrane and inhibition of aminophospholipid translocase. Biochim. Biophys. Acta 1026: 153-160

45. Bitbol M, Fellmann P, Zachowski A and Devaux PF (1987) lon regulation of phosphatidylserine and phosphatidylethanolamine outside-inside translocation in human erythrocytes. Biochim. Biophys. Acta 904: 268-282

46. Lin S, Yang E and Huestis WH (1994) Relationship of phospholipid distribution to shape change in $\mathrm{Ca}(2+)$-crenated and recovered human erythrocytes. Biochemistry 33: 7337-7344

47. Williamson P, Kulick A, Zachowski A, Schlegel RA and Devaux PF (1992) Ca2+ induces transbilayer redistribution of all major phospholipids in human erythrocytes. Biochemistry 31: $6355-6360$
48. Basse F, Stout JG, Sims PJ and Wiedmer T (1996) Isolation of an erythrocyte membrane protein that mediates $\mathrm{Ca} 2+$-dependent transbilayer movement of phospholipid. J. Biol. Chem. 271: 17205-17210

49. Comfurius $P$, Williamson $P$, Smeets EF, Schlegel RA, Bevers EM and Zwaal RFA (1996) Reconstitution of phospholipid scramblase activity from human blood platelets. Biochemistry 35: 7631-7634

50. Zhou QS, Zhao J, Stout JG, Luhm RA, WiedmerT and Sims PJ (1997) Molecular cloning of human plasma membrane phospholipid scramblase a protein mediating transbilayer movement of plasma membrane phospholipids. J. Biol. Chem. 272: 18240-18244

51. Zhou QS, Sims PJ and Wiedmer T (1998) Expression of proteins controlling transbilayer movement of plasma membrane phospholipids in the $\mathrm{B}$ lymphocytes from a patient with Scott syndrome. Blood 92: 1707-1712

52. Janel N, Leroy C, Laude I, Toti F, Fressinaud E, Meyer D, Freyssinet JM and KerbiriouNabias D (1999) Assessment of the expression of candidate human plasma membrane phospholipid scramblase in Scott syndrome cells. Thrombosis Haemostasis 81: $322-323$

53. Verhoven B, Schlegel RA and Williamson P (1995) Mechanisms of phosphatidylserine exposure, a phagocyte recognition signal, on apoptotic $T$ lymphocytes. J. Exp. Med. 182: 1597-1601

54. Schlegel RA, Callahan M, Krahling S, Pradhan D and Williamson P (1996) Mechanisms for recognition and phagocytosis of apoptotic lymphocytes by macrophages. Adv. Exp. Med. Biol. 406: 21-28

55. Schlegel RA, Stevens M, Lumley-Sapanski Kand Williamson P (1993) Altered lipid packing identifies apoptotic thymocytes. Immunol. Lett. 36: 283-288

56. Martin SJ, Reutelingsperger CPM, Mcgahon AJ, Rader JA, Vanschie RCAA, Laface DM and Green DR (1995) Early redistribution of plasma membrane phosphatidylserine is a general feature of apoptosis regardless of the initiating stimulus: Inhibition by overexperssion of Bcl-2 and Abl. J. Exp. Med. 182: 1545-1556

57. Bennett MR, Gibson DF, Schwartz SM and Tait JF (1995) Binding and phagocytosis of apoptotic vascular smooth muscle cells is mediated in part by exposure of phosphatidylserine. Circ. Res. 77: 1136-1142

58. Bombeli T, Karsan A, Tait JF and Harlan JM (1997) Apoptotic vascular endothelial cells become procoagulant. Blood 89: 2429-2442

59. Shiratsuchi A, Umeda M, Ohba $Y$ and Nakanishi $Y$ (1997) Recognition of phosphatidylserine on the surface of apoptotic spermatogenic cells and subsequent phagocytosis by sertoli cells of the rat. J. Biol. Chem. 272: 2354 2358

60. Walton M, Sirimanne E, Reutelingsperger C, Williams C, Gluckman P and Dragunow M (1997) Annexin V labels apoptotic neurons following hypoxiaischemia. Neuroreport 8: $3871-3875$

61. Bourez RL, Mathijssen IM, Vaandrager JM and Vermeij-Keers C (1997) Apoptotic cell death during normal embryogenesis of the coronal suture: early detection of apoptosis in mice using annexin V. J. Craniofac. Surg. 8: 441-445

62. Van den Eijnde SM, Boshart L, Reutelingsperger CPM, DeZeeuw Cl and Vermeij-Keers C (1997) Phosphatidylserine plasma membrane asymmetry in vivo: A pancellular phenomenon which alters during apoptosis. Cell Death Differ. 4: 311-316

63. Van den Eijnde SM, Boshart L, Reutelingsperger CPM, De Zeeuw Cl and VermeijKeers C (1997) Phosphatidylserine is exposed by apoptotic cells in mouse embryos in vivo. Eur. J. Morphol. 35: 54-55

64. Van den Eijnde SM, Boshart L, Reutelingsperger CPM, DeZeeuw $\mathrm{Cl}$ and VermeijKeers CHR (1997) Annexin V: A new marker for in situ detection of apoptotic cell death at the light microscopical and ultrastructural level during embryogenesis and metamorphosis. Eur. J. Morphol. 35: 40-40

65. van den Eijnde SM, Luijsterburg AJM, Boshart L, DeZeeuw $\mathrm{Cl}$, vanDierendonck $\mathrm{JH}$, Reutelingsperger CPM and VermeijKeers C (1997) In situ detection of apoptosis during embryogenesis with Annexin V: From whole mount to ultrastructure. Cytometry 29: 313-320

66. van den Eijnde SM, Boshart L, Baehrecke EH, DeZeeuw Cl, Reutelingsperger CPM and VermeijKeers C (1998) Cell surface exposure of phosphatidylserine during apoptosis is phylogenetically conserved. Apoptosis 3: $9-16$

67. van den Eijnde SM, Lips J, Boshart L, Vermeij-Keers C, Marani E, Reutelingsperger CP and De Zeeuw Cl (1999) Spatiotemporal distribution of dying neurons during early mouse development. Eur. J. Neurosci. 11:712-724 
68. Bratton DL, Fadok VA, Richter DA, Kailey JM, Guthrie LA and Henson PM (1997) Appearance of phosphatidylserine on apoptotic cells requires calciummediated nonspecific flip-flop and is enhanced by loss of the aminophospholipid translocase. J. Biol. Chem. 272: 26159-26165

69. Verhoven B, Krahling S, Schlegel RA and Williamson P (1999) Regulation of phosphatidylserine exposure and phagocytosis of apoptotic $T$ lymphocytes. Cell Death Differ. 6: 262-270

70. Hampton MB, Vanags DM, PornAres MI and Orrenius S (1996) Involvement of extracellular calcium in phosphatidylserine exposure during apoptosis. FEBS Lett. 399: 277-282

71. Frasch SC, Henson PM, Kailey JM, Richter DA, Janes MS, Fadok VA and Bratton DL (2000) Regulation of phospholipid scramblase activity during apoptosis and cell activation by protein kinase $\mathrm{C}$ delta. J. Biol. Chem. 275: 23065-23073

72. Bratton DL, Fadok VA, Richter DA, Kailey JM, Frasch SC, Nakamura T and Henson PM (1999) Polyamine regulation of plasma membrane phospholipid flip-flop during apoptosis. J. Biol. Chem. 274: 28113-28120

73. Martin SJ, Finucane DM, AmaranteMendes GP, OBrien GA and Green DR (1996) Phosphatidylserine externalization during CD95-induced apoptosis of cells and cytoplasts requires ICE/CED-3 protease activity. J. Biol. Chem. 271: 28753-28756

74. Zhuang JG, Ren Y, Snowden RT, Zhu HJ, Gogvadze V, Savill JS and Cohen GM (1998) Dissociation of phagocyte recognition of cells undergoing apoptosis from otherfeatures of the apoptotic program. J. Biol. Chem. 273: 15628-15632

75. Well M, Jacobson MD and Raff MC (1998) Are caspases involved in the death of cells with a transcriptionally inactive nucleus? Sperm and chicken erythrocytes. J. Cell Sci. 111: 2707-2715

76. Cecconi F, AlvarezBolado G, Meyer BI, Roth KA and Gruss P (1998) Apaf1 (CED-4 homolog) regulates programmed cell death in mammalian development. Cell 94: 727-737

77. Zou H, Henzel WJ, Liu XS, Lutschg A and Wang XD (1997) Apaf-1, a human protein homologous to C-elegans CED-4, participates in cytochrome cdependent activation of caspase-3. Cell 90: 405-413

78. Tanaka KI and Ohnishi S (1976) Heterogeneity in the fluidity of intact erythrocyte membrane and its homogenization upon hemolysis. Biochim. Biophys. Acta 426: 218-231

79. Williamson P, Bateman J, Kozarsky K Mattocks K, Hermanowicz N, Choe HR and Schlegel RA (1982) Involvement of spectrin in the maintenance of phasestate asymmetry in the erythrocyte membrane. Cell 30: 725-733

80. Morrot G, Cribier S, Devaux PF, Geldwerth D, Davoust J, Bureau JF, Fellmann $P$, Herve P and Frilley B (1986) Asymmetric lateral mobility of phospholipids in the human erythrocyte membrane. Proc. Natl. Acad. Sci. USA 83: 6863-6867

81. Fadok VA, Savill JS, Haslett C, Bratton DL, Doherty DE, Campbell PA and Henson PM (1992) Different populations of macrophages use either the vitronectin receptor or the phosphatidylserine receptor to recognize and remove apoptotic cells. J. Immunol. 149: 4029-4035

82. Krahling S, Callahan MK, Williamson P and Schlegel RA (1999) Exposure of phosphatidylserine is a general feature in the phagocytosis of apoptotic lymphocytes by macrophages. Cell Death Differ. 6: 183-189

83. Schlegel R and Williamson P (1988) Role of phospholipid asymmetry in cellular membrane fusion. In: Ohki S, Doyle D, Flanagan TD, Hui SE, Mayhew E (eds) Molecular Mechanisms of Membrane Fusion. pp 289-301. Plenum Press, New York

84. Callahan MK, Williamson P and Schlegel RA (2000) Surface expression of phosphatidylserine on macrophages is required for phagocytosis of apoptotic thymocytes. Cell Death Differ. 7: 645-653

85. Fadok VA, Bratton DL, Rose DM, Pearson A, Ezekewitz RA and Henson PM (2000) A receptor for phosphatidylserine-specific clearance of apoptotic cells. Nature 405: 85-90

86. Albert ML, Pearce SF, Francisco LM, Sauter B, Roy P, Silverstein RL and Bhardwaj N (1998) Immature dendritic cells phagocytose apoptotic cells via alphavbeta5 and CD36, and cross-present antigens to cytotoxic T lymphocytes. J. Exp. Med. 188: 1359-1368

87. MoffattOD, DevittA, Bell ED, Simmons DL and Gregory CD (1999) Macrophage recognition of ICAM-3 on apoptotic leukocytes. J. Immunol. 162: 6800-6810

88. Savill J, Hogg N, Ren Y and Haslett C (1992) Thrombospondin cooperates with CD36 and the vitronectin receptor in macrophage recognition of neutrophils undergoing apoptosis. J. Clin. Invest. 90: 1513-1522
89. Fukasawa M, Adachi H, Hirota K, Tsujimoto M, Arai Hand Inoue K (1996) SRB1, a class $B$ scavenger receptor, recognizes both negatively charged liposomes and apoptotic cells. Exp. Cell Res. 222: 246-250

90. Franc NC, Heitzler P, Ezekowitz RAB and White K (1999) Requirement for croquemort in phagocytosis of apoptotic cells in Drosophila. Science 284: $1991-1994$

91. Krieger M and Herz J (1994) Structures and functions of multiligand lipoprotein receptors: macrophage scavenger receptors and $L D L$ receptor-related protein (LRP). Ann. Rev. Biochem. 63: 601-637

92. Fadok VA, Warner ML, Bratton DL and Henson PM (1998) CD36 is required for phagocytosis of apoptotic cells by human macrophages that use either a phosphatidylserine receptor or the vitronectin receptor (alpha(v)beta(3)). J. Immunol. 161: 6250-6257

93. Platt N, Suzuki H, Kodama T and Gordon S (2000) Apoptotic thymocyte clearance in scavenger receptor class A-deficient mice is apparently normal. J. Immunol. 164: 4861-4867

94. Ulevitch RJ and Tobias PS (1995) Receptor-dependent mechanisms of cell stimulation by bacterial endotoxin. Ann. Rev. Immunol. 13: 437-457

95. Devitt A, Moffatt OD, Raykundalia C, Capra JD, Simmons DL and Gregory CD (1998) Human CD14 mediates recognition and phagocytosis of apoptotic cells. Nature 392: 505-509

96. Flora PK and Gregory CD (1994) Recognition of apoptotic cells by human macrophages: Inhibition by a monocyte/macrophage-specific monoclonal antibody. Eur. J. Immunol. 24: 2625-2632

97. Schlegel RA, Krahling S, Callahan MK and Williamson P (1999) CD14 is a component of multiple recognition systems used by macrophages to phagocytose apoptotic lymphocytes. Cell Death Differ. 6: 583-592

98. Wang PY, Kitchens RL and Munford RS (1998) Phosphatidylinositides bind to plasma membrane CD14 and can prevent monocyte activation by bacterial lipopolysaccharide. J. Biol. Chem. 273: 24309-24313

99. Jacobson MD, Burne JF and Raff MC (1994) Programmed cell death and Bcl-2 protection in the absence of a nucleus. EMBO J. 13: 1899-1910

100. Weil M, Jacobson MD, Coles HS, Davies TJ, Gardner RL, Raff KD and Raff MC (1996) Constitutive expression of the machinery for programmed cell death. J. Cell Biol. 133: 1053-1059

101. Fadok VA, de Cathelineau A, Daleke DL, Henson PM and Bratton DL (2000) Loss of phospholipid asymmetry and surface exposure of phosphatidylserine is required for phagocytosis of apoptotic cells by macrophages and fibroblasts. J. Biol. Chem. (in press)

102. Schlegel RA, Callahan MK and Williamson $P$ (2001) The central role of phosphatidylserine in the phagocytosis of apoptotic thymocytes. Ann. NY Acad. Sci. 926: 217-225

103. Liu QA and Hengartner MO (1998) Candidate adaptor protein CED-6 promotes the engulfment of apoptotic cells in C. elegans. Cell 93: 961-972

104. Voll RE, Herrmann M, Roth EA, Stach C, Kalden JR and Girkontaite I (1997) Immunosuppressive effects of apoptotic cells [letter]. Nature 390: 350-351

105. Fadok VA, Bratton DL, Konowal A, Freed PW, Westcott JY and Henson PM (1998) Macrophages that have ingested apoptotic cells in vitro inhibit proinflammatory cytokine production through autocrine/paracrine mechanisms involving TGF-beta, PGE2, and PAF. J. Clin. Invest. 101: 890-898

106. Reddien PW and Horvitz HR (2000) CED-2/CrkIl and CED-10/Rac control phagocytosis and cell migration in Caenorhabditis elegans. Nature Cell Biol. 2: $131-136$

107. Stupack DG, Cho SY and Klemke RL (2000) Molecular signaling mechanisms of cell migration and invasion. Immunol. Res. 21: 83-88

108. Wu YC and Horvitz HR (1998) The C. elegans cell corpse engulfment gene ced7 encodes a protein similar to ABC transporters. Cell 93: 951-960

109. Higgins CF (1992) ABC transporters: from microorganisms to man. Ann. Rev Cell Biol. 8: 67-113

110. Ueda K, Matsuo M, Tanabe K, Morita K, Kioka N and Amachi T (1999) Comparative aspects of the function and mechanism of SUR1 and MDR1 proteins. Biochim. Biophys. Acta 1461: 305-313

111. Sheppard DN and Welsh MJ (1999) Structure and function of the CFTR chloride channel. Physiol. Rev. 79: S23-45

112. Borst $P$, Evers R, Kool M and Wijnholds J (1999) The multidrug resistance protein family. Biochim. Biophys. Acta 1461: 347-357 
113. Luciani MF and Chimini G (1996) The ATP binding cassette transporter ABC1, is required for the engulfment of corpses generated by apoptotic cell death. EMBO J. 15: 226-235

114. Hamon Y, Broccardo C, Chambenoit O, Luciani MF, Toti F, Chaslin S Freyssinet JM, Devaux PF, McNeish J, Marguet D and Chimini G (2000) ABC1 promotes engulfment of apoptotic cells and transbilayer redistribution of phosphatidylserine. Nature Cell Biol. 2: 399-406

115. Marguet D, Luciani MF, Moynault A, Williamson P and Chimini G (1999) Engulfment of apoptotic cells involves the redistribution of membrane phosphatidylserine on phagocyte and prey. Nature Cell Biol. 1: 454-456

116. Orso E, Broccardo C, Kaminski WE, Bottcher A, Liebisch G, Drobnik W, Gotz A, Chambenoit O, Diederich W, Langmann T, Spruss T, Luciani MF, Rothe G, Lackner KJ, Chimini G and Schmitz G (2000) Transport of lipids from Golgi to plasma membrane is defective in Tangier disease patients and Abc1-deficient mice. Nature Genet. 24: 192-196

117. Marcil M, BrooksWilson A, Clee SM, Roomp K, Zhang LH, Yu L, Collins JA vanDam M, Molhuizen HOF, Loubster O, Ouellette BFF, Sensen CW, Fichter K, Mott S, Denis M, Boucher B, Pimstone S, Genest J, Kastelein JJP and Hayden MR (1999) Mutations in the ABC1 gene in familial HDL deficiency with defective cholesterol efflux. Lancet 354: 1341-1346

118. Lawn RM, Wade DP, Garvin MR, Wang XB, Schwartz K, Porter JG, Seilhamer JJ, Vaughan AM and Oram JF (1999) The Tangier disease gene product ABC1 controls the cellular apolipoprotein-mediated lipid removal pathway. J. Clin. Invest. 104: R25-R31

119. BrooksWilson A, Marcil M, Clee SM, Zhang LH, Roomp K, vanDam M, Yu L, Brewer C, Collins JA, Molhuizen HOF, Loubser O, Ouelette BFF, Fichter K, AshbourneExcoffon KJD, Sensen CW, Scherer S, Mott S, Denis M, Martindale D, Frohlich J, Morgan K, Koop B, Pimstone S, Kastelein JJP, Genest J and Hayden MR (1999) Mutations in ABC1 in Tangier disease and familial highdensity lipoprotein deficiency. Nature Genet. 22: 336-345

120. Bodzioch M, Orso E, Klucken T, Langmann T, Bottcher L, Diederich W, Drobnik W, Barlage S, Buchler C, PorschOzcurumez M, Kaminski WE, Hahmann HW, Oette K, Rothe G, Aslanidis C, Lackner KJ and Schmitz G (1999) The gene encoding ATP-binding cassette transporter 1 is mutated in Tangier disease. Nature Genet. 22: 347-351

121. Rust S, Rosier M, Funke H, Real J, Amoura Z, Piette JC, Deleuze JF, Brewer HB, Duverger N, Denefle P and Assmann G (1999) Tangier disease is caused by mutations in the gene encoding ATP-binding cassette transporter 1 . Nature Genet. 22: 352-355

122. von Eckardstein A, Chirazi A, Schuler-Luttmann S, Walter M, Kastelein JJ, Geisel J, Real JT, Miccoli R, Noseda G, Hobbel G and Assmann G (1998) Plasma and fibroblasts of Tangier disease patients are disturbed in transferring phospholipids onto apolipoprotein A-I. J. Lipid Res. 39: 987-998

123. Parnaik R, Raff MC and Scholes J (2000) Differences between the clearance of apoptotic cells by professional and non-professional phagocytes. Curr. Biol. 10: $857-860$

124. Sambrano GR, Terpstra $V$ and Steinberg $D$ (1997) Independent mechanisms for macrophage binding and macrophage phagocytosis of damaged erythrocytes - evidence of receptor cooperativity. Arterioscl. Thromb. Vasc. Biol. 17: 3442-3448

125. Licht R, Jacobs CWM, Tax WJM and Berden JHM (1999) An assay for the quantitative measurement of in vitro phagocytosis of early apoptotic thymocytes by murine resident peritoneal macrophages. J. Immunol. Methods 223: $237-248$

126. Bevers EM, Tilly RH, Senden JM, Comfurius P and Zwaal RFA (1989) Exposure of endogenous phosphatidylserine at the outer surface of stimulated platelets is reversed by restoration of aminophospholipid translocase activity. Biochemistry 28: 2382-2387

127. Williamson $P$, Bevers EM, Smeets EF, Comfurius $P$, Schlegel RA and Zwaal RFA (1995) Continuous analysis of the mechanism of activated transbilayer lipid movement in platelets. Biochemistry 34: 10448-10455

128. Zwaal RF, Comfurius P and Bevers EM (1998) Lipid-protein interactions in blood coagulation. Biochim. Biophys. Acta 1376: 433-453

129. Gilbert GE and Arena AA (1996) Activation of the factor VIIla-factor IXa enzyme complex of blood coagulation by membranes containing phosphatidyl-Lserine. J. Biol. Chem. 271: 11120-11125

130. Gilbert GE and Drinkwater D (1993) Specific membrane binding of factor VIII is mediated by O-phospho-L-serine, a moiety of phosphatidylserine. Biochemistry 32: 9577-9585
131. Comfurius P, Smeets EF, Willems GM, Bevers EM and Zwaal RFA (1994) Assembly of the prothrombinase complex on lipid vesicles depends on the stereochemical configuration of the polar headgroup of phosphatidylserine. Biochemistry 33: 10319-10324

132. Krishnaswamy S, Jones KC and Mann KG (1988) Prothrombinase complex assembly. Kinetic mechanism of enzyme assembly on phospholipid vesicles. J. Biol. Chem. 263: 3823-3834

133. Vermeer C (1990) Gamma-carboxyglutamate-containing proteins and the vitamin K-dependent carboxylase. Biochem. J. 266: 625-636

134. Spaargaren J, Giesen PL, Janssen MP, Voorberg J, Willems GM and van Mourik JA (1995) Binding of blood coagulation factor VIII and its light chain to phosphatidylserine/phosphatidylcholine bilayers as measured by ellipsometry. Biochem. J. 310: 539-545

135. Kulman JD, Harris JE, Haldeman BA and Davie EW (1997) Primary structure and tissue distribution of two novel proline-rich gamma-carboxyglutamic acid proteins. Proc. Natl. Acad. Sci. USA 94: 9058-9062

136. Sims PJ, Wiedmer T, Esmon CT, Weiss HJ and Shattil SJ (1989) Assembly of the platelet prothrombinase complex is linked to vesiculation of the platelet plasma membrane. Studies in Scott syndrome: an isolated defect in platelet procoagulant activity. J. Biol. Chem. 264: 17049-17057

137. Bettache N, Gaffet P, Allegre N, Maurin L, Toti F, Freyssinet JM and Bienvenue A (1998) Impaired redistribution of aminophospholipids with distinctive cell shape change during $\mathrm{Ca}^{2+}$-induced activation of platelets from a patient with Scott syndrome. Br. J. Haematol. 101: 50-58

138. Bevers EM, Wiedmer T, Comfurius $P$, Shattil SJ, Weiss HJ, Zwaal RFA and Sims PJ (1992) Defective $\mathrm{Ca}^{2+}$-induced microvesiculation and deficient progression of procoagulant activity in erythrocytes from a patient with a bleeding disorder-A study of the red blood cells of Scott syndrome. Blood 79: $380-388$

139. Kojima H, Newtonnash D, Weiss HJ, Zhao J, Sims PJ and Wiedmer T (1994) Production and characterization of transformed B-lymphocytes expressing the membrane defect of Scott syndrome. J. Clin. Invest. 94: 2237-2244

140. Sessions A and Horwitz AF (1981) Myoblast aminophospholipid asymmetry differs from that of fibroblasts. FEBS Lett. 134: 75-78

141. Weiss $L$ (1965) The structure of bone marrow. Functional interrelationships of vascular and hematopoietic compartments in experimental hemolytic anemia: an electron microscopic study. J. Morphol. 117: 467-537

142. Skutelsky E and Danon D (1967) An electron microscopic study of nuclear elimination from the late erythroblast. J. Cell Biol. 33: 625-635

143. Bessis M (1977) Blood Smears Reinterpreted. Springer-Verlag, New York

144. Schlegel RA, Phelps BM, Waggoner A, Terada $L$ and Williamson $P$ (1980) Binding of merocyanine 540 to normal and leukemic erythroid cells. Cell 20: $321-328$

145. Schlegel RA, Phelps BM, Cofer GP and Williamson P (1982) Enucleation eliminates a differentiation-specific surface marker from normal and leukemic murine erythroid cells. Exp. Cell Res. 139: 321-328

146. Williamson $P$, Bevers EM, Smeets EF, Comfurius $P$, Schlegel RA and Zwaal RFA (1995) Continuous analysis of the mechanism of activated transbilayer lipid movement in platelets. Biochemistry 34: 10448-10455

147. Bevers EM, WiedmerT, Comfurius $P$, Zhao J, Smeets EF, Schlegel RA, Schroit AJ, Weiss HJ, Williamson P, Zwaal RFA and Sims PJ (1995) The complex of phosphatidylinositol 4,5-bisphosphate and calcium ions is not responsible for $\mathrm{Ca}(2+)$-induced loss of phospholipid asymmetry in the human erythrocyte: a study in Scott syndrome, a disorder of calcium-induced phospholipid scrambling. Blood 86: 1983-1991

148. Geiduschek JB and Singer SJ (1979) Molecular changes in the membranes of mouse erythroid cells accompanying differentiation. Cell 16: 149-163

149. Allan D, Limbrick AR, Thomas P and Westerman MP (1982) Release of spectrin-free spicules on reoxygenation of sickled erythrocytes. Nature 295: 612-613

150. Allan D, LimbrickAR, Thomas P and Westerman MP (1981) Microvesicles from sickle erythrocytes and their relation to irreversible sickling. Br. J. Haematol. 47: 383-390

151. Choe HR, Schlegel RA, Rubin E, Williamson P and Westerman MP (1986) Alteration of red cell membrane organization in sickle cell anaemia. Br. J. Haematol. 63: 761-773 
152. Kuypers FA, Lewis RA, Hua M, Schott MA, Discher D, Ernst JD and Lubin BH (1996) Detection of altered membrane phospholipid asymmetry in subpopulations of human red blood cells using fluorescently labeled annexin V. Blood 87: $1179-1187$

153. Wood BL, Gibson DF and Tait JF (1996) Increased erythrocyte phosphatidylserine exposure in sickle cell disease: Flow-cytometric measurement and clinical associations. Blood 88: 1873-1880

154. Westerman MP, Green D, Gilman-Sachs A, Beaman K, Freels S, Boggio L, Allen S, Zuckerman L, Schlegel R and Williamson P (1999) Antiphospholipid antibodies, proteins $\mathrm{C}$ and $\mathrm{S}$, and coagulation changes in sickle cell disease. J. Lab. Clin. Med. 134: 352-362

155. Lew VL, Hockaday A, Sepulveda MI, Somlyo AP, Somlyo AV, Ortiz OE and Bookchin RM (1985) Compartmentalization of sickle-cell calcium in endocytic inside-out vesicles. Nature 315: 586-589

156. Williamson P, Puchulu E, Penniston JT, Westerman MP and Schlegel RA (1992) $\mathrm{Ca}^{2+}$ accumulation and loss by aberrant endocytic vesicles in sickle erythrocytes. J. Cell Physiol. 152: 1-9

157. Galli M and Bevers EM (1994) Blood cell lipid asymmetry and antiphospholipid antibodies. Haemostasis 24: 183-190

158. Galli M, Barbui T, Zwaal RFA, Comfurius P and Bevers EM (1993) Antiphospholipid antibodies - Involvement of protein cofactors. Haematologica 78: $1-4$

159. Casciolarosen L, Rosen A, Petri M and Schlissel M (1996) Surface blebs on apoptotic cells are sites of enhanced procoagulant activity: Implications for coagulation events and antigenic spread in systemic lupus erythematosus. Proc. Natl. Acad. Sci. USA 93: 1624-1629

160. Balasubramanian K and Schroit AJ (1998) Characterization of phosphatidylserine-dependent beta(2)-glycoprotein I macrophage interactions-implications for apoptotic cell clearance by phagocytes. J. Biol. Chem. 273: 29272 29277

161. Manfredi AA, Rovere P, Heltai S, Galati G, Nebbia G, Tincani A, Balestrieri G and Sabbadini MG (1998) Apoptotic cell clearance in systemic lupus erythematosus II. Role of beta(2)-glycoprotein I. Arthritis Rheumatism 41: $215-223$
162. Schwartz BR, Karsan A, Bombeli T and Harlan JM (1999) A novel beta 1 integrin-dependent mechanism of leukocyte adherence to apoptotic cells. J. Immunol. 162: 4842-4848

163. Sambrano GR and Steinberg D (1995) Recognition of oxidatively damaged and apoptotic cells by an oxidized low density lipoprotein receptor on mouse peritoneal macrophages: Role of membrane phosphatidylserine. Proc. Natl. Acad. Sci. USA 92: 1396-1400

164. PlattN, SuzukiH, Kurihara Y, Kodama T and Gordon S (1996) Role for the class A macrophage scavenger receptor in the phagocytosis of apoptotic thymocytes in vitro. Proc. Natl. Acad. Sci. USA 93: 12456-12460

165. Franc NC, Dimarcq JL, Lagueux M, Hoffmann J and Ezekowitz RAB (1996) Croquemort, a novel Drosophila hemocyte/macrophage receptor that recognizes apoptotic cells. Immunity 4: 431-443

166. Dini L, Autuori F, Lentini A, Oliverio S and Piacentini M (1992) The clearance of apoptotic cells in the liver is mediated by the asialoglycoprotein receptor. FEBS Lett. 296: $174-178$

167. Duvall E, Wyllie AH and Morris RG (1985) Macrophage recognition of cells undergoing programmed cell death (apoptosis). Immunology 56: 351-358

168. Wu YC and Horvitz HR (1998) C-elegans phagocytosis and cell-migration protein CED-5 is similar to human DOCK180. Nature 392: $501-504$

169. Mevorach D, Mascarenhas JO, Gershov D and Elkon KB (1998) Complementdependent clearance of apoptotic cells by human macrophages. J. Exp. Med 188: $2313-2320$

170. Taylor PR, Carugati A, Fadok VA, Cook HT, Andrews M, Carroll MC, Savill JS Henson PM, Botto M and Walport MJ (2000) A hierarchical role for classical pathway complement proteins in the clearance of apoptotic cells in vivo. J. Exp. Med. 7: $359-366$

171. Botto M, Dell'Agnola C, Bygrave AE, Thompson EM, Cook HT, Petry F, Loos M Pandolfi PP and Walport MJ (1998) Homozygous C1q deficiency causes glomerulonephritis associated with multiple apoptotic bodies. Nature Genet. 19: $56-59$

172. Ishimoto Y, OhashiK, MizunoKand NakanoT(2000) Promotion of the uptake of PS liposomes and apoptotic cells by a product of growth arrest-specific gene gas6. J. Biochem. (Tokyo) 127: 411-417 